\title{
The Development of Computer Policies in Government, Political Parties, and Trade Unions in Norway 1961-1983
}

\author{
Knut Elgsaas ${ }^{1}$ and Håvard Hegna ${ }^{2}$ \\ ${ }^{1}$ Researcher/Project director at the Norwegian Computing Center 1963-1973, \\ Head of Division at the Norwegian Telecommunication Administration, 1973-1980, \\ Managing director of Oslo Data, the Computing Center of City of Oslo, 1980-1991 \\ elgsaas@c2i.net \\ ${ }^{2}$ Senior Research Scientist (emeritus) at the Norwegian Computing Center 1962-2006 \\ hegna@nr.no
}

\begin{abstract}
A "Council for Government Electronic Data Processing" was established in 1961. This was the start of development of a common policy for computers and data within the public administration. In 1969-70, computers got on the agenda of political parties and the trade unions. In the course of the seventies and the beginning of the eighties the government, the political parties, and the trade unions established a more comprehensive view of data political questions that we will designate by the term data policy. This paper puts some light on the causes and forces that drove the evolvement of a data policy within these central sectors in Norway. We will also show how various actors of research, trade and industry, and political life influenced the development of data policy and present links between the actors that indicate that they mutually influenced each other.
\end{abstract}

Keywords: Data policy, Norway, government, politics, trade union.

\section{Introduction}

A well-functioning public sector is a prerequisite for the continuation, development, and acceptance of the welfare state. Since the end of the 1950s, this has meant a growing and timely use of computers and data processing in public administration. Norway's Central Bureau of Statistics (Statistisk Sentralbyrå, SSB) started using punched card equipment, made by Hollerith, for the census as early as in 1894. Public electronic data processing began in 1958 when SSB installed its first electronic computer, an English Electric DEUCE MARK II that was run by the Norwegian Computing Center (NCC) ${ }^{1}$. That same year, an IBM 650 at Bergen University and

${ }^{1}$ NCC, Norsk Regnesentral, was established in 1952 by The Royal Norwegian Council for Technical and Scientific Research as a national coordinator of computing for pure and applied research. SSB had no experience with neither running a data processing facility nor do any programming in 1958, so NCC was offered the responsibility of running and administering the use of the SSB computer. In the 1960s, NCC was a combined computing facility and research institute in computer science and quantitative methods, see [9]. After 1970, while keeping the same, now somewhat confusing, name, NCC was re-focused and has since been a research foundation [18]. 
West Norway Punched Card Center (Holkortsentralen for Vestlandet) was used for the calculation of taxes for the the Ministry of Finance. Several public services were on the verge of replacing or complementing their punched card equipment with electronic computers in the next few years.

Computers were expensive and huge machines, costly to run and costly to program. The Government saw a need for coordinating public data processing and in 1961 established a "Council for Government Electronic Data Processing” (Rådet for elektronisk databehandling i staten, DB-rådet). This was the start of development of a common policy for computers and data within the public administration. During the sixties and seventies the Government, the political parties, and the organisations of employers and employees developed a more comprehensive view of data political questions that attempted to establish policies and tools to take advantage of the benefits and manage the threats that came with the new technology. It is these comprehensive policies which we will designate by the term data policy.

DB-rådet was to consider questions of importance concerning public data processing and was given a wide mandate. DB-rådet should lay down regulatory lines, advise about acquisitions, promote integration and coordinate the use of data processing equipment, and evaluate the results. In 1974, a specific point about promoting longterm integration and coordination was added to the mandate [15]. During the coming years, DB-rådet and its secretariat, which was led by Kåre Fløisand, had a strong influence on the computer situation in the public sector. Fløisand, who had a background as assistant at the previously mentioned IBM 650 installation in Bergen, was the head of the Data Processing Department of the Government Institution of Organization and Management (R-direktoratet). One particular result of the work of DBrådet was the proposal in 1970 to establish a central public data facility, the State Computing Center (Statens Driftsentral, SDS). Leif Olaussen, the Head of Planning in R-direktoratet and former Director of the Norwegian Computing Center, led the work leading to the proposal. Fløisand was chosen as the leader of the project group that planned SDS, which was to be the common service facility for small and medium sized public services [12]. SDS was established in 1972.

DB-rådet did not stop there; it wanted to go further on the line of centralization of public computing. In the opinion of DB-rådet, a joint plan for system development and data processing for the whole public sector was needed. A government report advocating this view came in 1973 [19]. DB-rådet secretariat leader Fløisand and Arne-Erik Hilmen of R-direktoratet wrote the report.

However, several main public institutions (Post Office, Telecommunication Administration, and National Insurance Administration) opposed DB-rådet and their view came through both in the Government and in the Parliament. The Minister for Consumer Affairs and Administration, the administrative superior of R-direktoratet, stated that administrative routines and systems development was the responsibility of the particular institution. They considered data processing a support function that did not need any central planning [29] ${ }^{2}$. The Parliament was of the same opinion as the Minister [14].

\footnotetext{
${ }^{2}$ In a private conversation with Elgsaas, a high executive of the Ministry for Consumer Affairs and Administration said that the DB-rådet secretariat leader was furious when he did not get the support of the Ministry.
} 


\section{The Public Sector I - Policy and Procurement}

The Norwegian data industry, including Norsk Data, Kongsberg Våpenfabrikk, Tandberg, and Mycron, grew up in the 1970s. Both the political parties and the trade unions urged that this new industry should be supported, mainly by requiring that government administrations and institutions buy Norwegian hardware and software. This in many cases led to conflicts in connection with computer procurements.

At the root of the conflicts lay the Government's incompatible goals and instructions for public procurements. A perspective analysis for Norwegian electronic industry [23] recommended that Norwegian electronic products, including data products, should be chosen by public institutions when they were as good as or better than foreign products and when the product was of a significant public importance or was seen as a course in the establishment of a new industrial development ${ }^{3}$. At the same time, public services were required to follow a set of rules for tenders that would lead to the selection of goods based on a total evaluation of price, quality, and other features of importance for the tasks for which the equipment was intended.

Each public enterprise, such as the State Railway (Norges Statsbaner), the Telecommunication Administration (Televerket), Norway Mail (Postverket), or public service, such as the National Insurance Administration (Rikstrygdeverket) and others, were at the same time required to do their work as efficiently as possible. If one of these public works preferred foreign products, problems arose. Public services had instructions to report their procurement plans to DB-rådet. DB-rådet should then give their comments. The leader of DB-rådet was also the leader of the Government Institution of Organization and Management (R-direktoratet) which acted as the secretariat for DB-rådet. This gave R-direktoratet a possibility to have considerable power and influence on computer procurements in the public sector. By playing on the side of the Ministry of Industry (Industridepartementet) and the political wish to support Norwegian computer industry, R-direktoratet exploited this possibility. Kåre Fløisand played a central role in this. Cooperation with the Ministry of Industry gave him the influence on public data processing that his own Ministry had denied him.

The role of DB-rådet, as the name implies, was only advisory, while the Ministry of Industry could impose their policy only on its subsidiary activities. However, there was a way around this. If DB-rådet and R-direktoratet were dissatisfied with a decision of a public institution to buy a foreign computer, the institution would be asked to deliver further clarifications and deliberations. Such demands could be stretched to absurdity. As an example, in the mid-1970s one institution was asked to produce a detailed plan for its computer activities until the year $2010^{4}$. This kind of deliberate procrastination worked in some cases. In the end, many institutions understood that if they should get any new computer equipment at all, they would have to buy a Norwegian computer.

\footnotetext{
${ }^{3}$ One member of the committee that did the analysis was Jan Balstad, representing The Norwegian Iron and Metal Workers Union, who had been a member of the steering committee for the Iron and Metal Project (see below).

${ }^{4}$ One of the authors referred to this incident and gave the name of the institution in a public speech in The Norwegian Computer Society on October 20, 1977 [10]. He was not corrected by R-direktoratet representatives in the audience, but he has not been able to reconfirm the information for the HINC2 conference.
} 
Regarding computer procurement, the most well known of these conflicts occurred in the National Insurance Administration (Rikstrygdeverket, RTV). RTV wanted a new computer solution based on a central IBM computer with communication to local insurance offices through a system of regional computer facilities already established for data processing to Norwegian local communities. R-direktoratet wanted a solution based on Norwegian computers and systems. The role of Kåre Fløisand shows through clearly in document from Ruth Drolsum and Arne-Erik Hilmen of the RTV Systems Department on June 23, 1977 [8]. They wrote:

“In September 1976 RTV forwarded a proposal for a test project for INFOTRYGD (the new information system for the National Insurance Administration). The case was taken up in DB-rådet. The DB-rådet secretariat under hand contacted Norsk Data and showed them the plans of RTV. Based on this information, and without first contacting RTV, Norsk Data put forward a sketch of a solution with a cost estimate. DB-rådet included this in its answer to the Ministry of Social Affairs and Health. RTV reaction to this procedure was strong. In a letter to the Ministry, RTV expressed that it considered this kind of practice principally unsound."

Hilmen had worked on the side of Fløisand only three years earlier. He now saw for himself the consequences of the recommendations supported by R-direktoratet.

After a long decision process, they decided that RTV should establish two different solutions. The first $40 \%$ of the local offices would connect to an RTV-system at IBM-based regional computing centers. The other $60 \%$ of the offices would use Norsk Data facilities with a separate RTV-system. Consequently, RTV had to maintain a very comprehensive set of regulations and databases on two different computer systems. The result of the "compromise" decision was a very costly and unsuitable solution for RTV [12].

After some years, the industrial policy that gave preference to Norwegian computer products came into discredit. It was unwound after the demise of Norsk Data in 1990-92. One reason why a public committee in 1978 (see below and [24]) proposed that the DB-rådet should cease its activities was the experience with how it attended its advisory role with respect to public computer procurement.

\section{The Trade Unions}

\subsection{The Iron- and Metal Project}

The Norwegian Iron- and Metal Workers Union (NJMF) in 1971 decided to establish a research project, strongly inspired by Professor Kristen Nygaard who was then Research Director at The Norwegian Computing Center (NCC). The project would contribute to a strengthening of the influence of trade unions and employees on the introduction and use of data systems and data technology in the work place [11].

The project came because of cooperation that had evolved from 1967 between Nygaard, employees at NCC, The Trade Union School (LO-skolen) at Sørmarka outside of Oslo, and several central representatives of NJMF and The Norwegian Confederation of Trade Unions (LO). In 1967, Nygaard had been asked to lecture on modern technology in a course named "The labour movement looks to the future" at LOskolen. This led to further lectures in local union shops as well as at LO-skolen. 
Nygaard was concerned that operations research, the Simula language that he designed at NCC with Professor Ole-Johan Dahl [3], and other IT-tools should not be used for the sole benefit of the owners and the employers. It was important that the workers should acquire the knowledge and competence necessary to influence the design of the workplace and their own working conditions. At the end of the 1960s, many local unions in connection with the introduction of numerically controlled machines approached NJMF. Both the central and the local level of the unions were uncertain about the new technology and the possible consequences of its use. The NJMF national congress in 1970 [16] made the following resolution:

"In connection with the development and use of computers, the congress underlines that a deliberate effort should be put forward to counteract the tendency to establish systems where humans are treated as a mechanical and programmable production factor. Where management is not willing to cooperate, the union must by themselves carry out such studies as will be necessary to strengthen the work place under the objectives of the workers and demand that the proposals that are brought forth shall be considered by the business management."

The time was therefore ripe when Nygaard suggested that NJMF should apply for research funding from the Royal Norwegian Council for Technical and Scientific Research (NTNF). The purpose of the application was "to build a base of knowledge at least equal to that which is available to the employers", as is stated in one of the notes that lay at the foundation of the decision of NJMF to send the application in 1970.

This was the first time that a trade union had applied for funding for this kind of a project. The application was to be handled by the Research Committee for Mechanical Industry, a subcommittee of NTNF. The committee held its meetings in the premises of The National Mechanical Industry Organization (MVL), i.e. the employer organization for this sector of Norwegian industry. MVL did not want a project where NJMF co-operated with "the radical researchers of the Norwegian Computing Center" . They tried to move the project over to The Norwegian Institute of Technology (Norges Tekniske Høyskole, NTH) in Trondheim, a research environment of which MVL felt more comfortable. The leadership of NJMF, with the full support of the leader Leif Skau, opposed this attempt by MVL to move the project. The project started at NCC in January of 1971.

Kristen Nygaard became the project leader. The project steering committee, led by Leif Skau, consisted of representatives from LO, Jan Balstad from NJMF, Knut Elgsaas from NCC, and representatives from several other research institutes (including Norwegian Productivity Institute (Norsk Produktivitetsinstitutt) and the Norwegian Work Research Institute (Arbeidsforskningsinstituttet)). Four local union shops, geographically spread over the southern part of Norway, were selected to take part in the project. These were located at Hydraulikk in Brattvåg, Kongsberg Våpenfabrikk in Kongsberg, Norwegian Electric Brown and Bovery (NEBB) in Oslo, and at Jonas Øglænd Bicycle Factory in Sandnes.

The original project plan included studies of one or more of the systems for planning and control that were set up for implementation in mechanical industries at the

${ }^{5}$ This NCC reputation was a result of the well publicized dispute between NCC and NTNF in 1969-70 [9]. 
time. Several documents along that line were produced in the spring of 1971. However, Nygaard noted that it was difficult for the union representatives from the shops to see any direct relevancy between this work plan and that which the representatives could use for concrete work at the various union levels. Nygaard saw that there was a danger that the reports would just end up in the shelves of the shop stewards, unused, maybe even unread.

It was important for NJMF and NCC that the project gave real and useful results. In a proposal from the project group suggesting a change of strategy and work focus that was adopted by the steering committee in the autumn of 1971, results were defined like this:

"Results are all actions from NJMF, centrally or at the local level, that with support from the project aim to give the organization and its members a larger influence on data processing and control tools in their work place."

"From this viewpoint, working papers and research reports from the project will be useful only to the extent that they lead to actions of the organization leadership, divisions, or local shops."

At first, the project group concentrated its work on establishing suitable educational material for shop stewards and industry employees. This resulted in the textbook "Planning, Control, and Data Processing, a basic textbook for trade unions". The book was available in May 1972 and was published by Tiden in 1974 [26].

The textbook formed the basis for the work started by the shops of the participating enterprises from the summer of 1972. The purpose was that the shops should test a way of working that the project group thought would be common in the future, "that shops themselves would study their important questions within their work place" with assistance from experts from outside and personnel from the business itself.

The shop at Hydraulikk made a business policy action program. The shop at Kongsberg evaluated a new control system, the shop at NEBB evaluated the organization, control systems, and working conditions, and the shop at Øglænd among other things made an evaluation of the planning of a new production building.

When the Iron- and Metal project ended in the spring of 1973, eight reports had been produced, including a final report and the four reports from the participating shops. About 120 people took part in the production of the reports. Among these were elected stewards and representatives of local shops and divisions as well as central people of NJMF, the project group and the steering committee [17].

The project was a very special one within Norwegian research at the time, both with respect to whom commissioned it and whose interests the project was to address. The definition of project results was also a special one. The results were not reports that gave academic merit to the researchers, but the actions that the research and studies triggered off at NJMF, at the local or central level.

The Iron- and Metal Project was later in the seventies followed by two similar three-year projects, first for The Norwegian Union of Commercial and Office Employees in 1976-78, later for The Norwegian Union of Chemical Industry Workers in $1977-79$ [13].

The Iron- and Metal Project also had other important consequences for trade union involvement in the introduction and use of new technology in Norway. The Data Agreement established between The Norwegian Confederation of Trade Unions (LO) 
and The Norwegian Employers Organization (NAF) in 1975 and two important sections in $\$ 12$ of the Working Environment Act of 1976 came as a direct result of the project and the engagement that it created in the trade unions.

\subsection{Data Agreements}

The set of agreements between employers and employees have always been a central means for the trade unions in their work to attend to the interests of their members. In 1974, the world's first data agreement was established between Viking-Askim AS and the local shop at the enterprise. The background was that the enterprise wanted to introduce a new data system for control of their car tire production. The trade union asked Kristen Nygaard for help in the discussions with the employer. The result was an agreement that gave the employees a right to information and participation in the design, introduction, and use of data systems in the enterprise. Less than a year later LO/NAF agreed on a "Framework for Systems based on Data Processing". A similar agreement was established between the government and trade unions in the public sector.

One presumption of the Data Agreements was that a local shop steward should have the opportunity to establish the competence necessary for evaluating the effect that the data systems would have on the working conditions. The workers had a long time negative experience with data experts brought in by the employers who lacked the ability to communicate with the workers and understand the problems connected with the introduction of new data systems.

\subsection{The Working Environment Act}

The new Working Environment Act was adopted in 1977. The act covered working hours, holidays, employment, etc. In $\$ 12$ on The Organization of Work a new provision was introduced in section 3 stating

\section{Concerning systems for control and planning.}

Workers and their elected representatives shall be kept continuously informed of systems used in planning and that are necessary to accomplish work, including planned changes to such systems. They shall be given the training necessary to familiarize themselves with the systems, and they shall take part in designing them [1].

This provision has the LO/NAF framework as its background, but covers systems for planning and control in general, not just those that are based on data systems. The provision applies to all enterprises in Norway. The Norwegian Labour Party was in power when the new Working Environment Act was prepared. Considering the strong ties between the Labour Party and LO, it was not difficult for central actors within the trade union movement, as well as for engaged members of the Labour Party, to influence the Government to introduce a provision like this in the new law. Torbjørn Berntsen, MP for the Labour Party, led the handling of the law in the Norwegian Parliament. He had been a local trade union leader for the iron- and metalworkers at Aker Mechanical Workshop, a large ship building enterprise, and he had close ties to the environment around Jan Balstad and other NJMF representatives with 
links to the Iron- and Metal Project and their demand for participation and influence on systems for control and planning.

\section{The Public Sector II}

In 1975, the Ministry of Consumers Affairs and Government administration appointed a committee to conduct an inquiry into the problems involved in decentralizing public data processing and improving its efficiency. The committee's terms of reference were as follows:

o To report on the future requirements for data processing in municipal, county, and national administration;

○ To evaluate the possibilities of decentralizing public data processing and making it an effective means in improving the efficiency in public institutions;

o To propose measures of an organizational, economic, system-analytical and technological nature to achieve the goals of decentralization and efficiency.

The leader of the committee was Knut Elgsaas, formerly Head of Projects at NCC and a member of the Iron- and Metal Project steering committee, now head of the Division for Rationalization in the Norwegian Telecommunication Administration. Among the committee members, one finds Ruth Drolsum, Head of Office in the Systems Department of RTV and Drude Berntsen, Director of NCC from 1970, and thus a former director for both Elgsaas and Kristen Nygaard, the leader of the Iron- and Metal Project. Director Drude Berntsen had been secretary to the Government appointed committee that reported on "Electronic Data Processing in the Health Service" one year earlier [21].

The committee, often referred to as the "Elgsaas committee" after the name of its leader, concluded its work in 1978 [24]. The Ministry, as is common procedure, sent the committee's report to a public hearing. In 1982 the Government presented a report on public data processing to the Parliament (Stortinget) based on the committee's report and the hearing [30].

The committee expected a strong growth in public data processing, especially in connection with economic systems, personal data systems and text processing systems. There would be more stringent quality requirements imposed on public data processing in the future. Decentralization of tasks to counties and municipalities would require new systems with better opportunities for interchange of data between public institutions. The committee emphasized the importance of developing common systems. Instead of the individual institution each developing its own data system for the same purpose, use of joint development of common systems would mean a reduction of cost for public administration. The committee expected that data terminals would be as common in public offices in the 1980s and 1990s as telephones and typewriters were around 1978. Computers of high processing and storage capacity would gradually become part of the ordinary office equipment.

To ensure an efficient use of new technology in public administration the committee proposed a series of practical means and measures concerning:

o Planning and budgeting of data processing;

o Systems development, maintenance and operation;

○ Introduction of quality control, DP-auditing; 
o Education;

O Research and development;

O Standards;

- Security and protection in public data processing;

o Statutes and regulations.

The committee pointed out that the number of candidates graduating annually with data processing as their main subject was far too low. There was an urgent need to increase the capacity of the educational system to meet the demand for skilled data professionals in public and private sector. It was proposed that the Ministry of Education prepared an educational plan concerning all aspects of data processing at the universities and colleges in Norway. The practical measures and proposals were generally welcomed in the hearing of the committee's report.

The committee also made proposals concerning the organization of public data processing. Norway had 435 municipalities at that time and 19 counties. Half of the municipalities had less than 5000 inhabitants. To build a base for decentralizing public data processing and use the scant resources in qualified data professionals most efficiently, the committee proposed the establishment and development of regional data centers offering services in public data processing. The seven existing municipal computing centers and the State Computer Center should be the pillars of support in the development of the new regional centers. The municipal data centers were located in different regions of Norway and were owned by municipalities and counties.

The committee was of the opinion that there was no longer a need for the Council for Government Electronic Data Processing. DB-rådet, against a minority of three who had been members of the above committee, fought for its continued existence in two reports in 1979 and 1980 [27]. Nevertheless, the Government agreed with the committee and the Council was abolished in 1980.

As might be expected, almost all counties and municipalities acclaimed the proposal of regional centers. Government Ministries were generally more reserved to the idea of regional centers while some were against it. That was quite natural; the establishment of regional centers would remove some influence and power from the Ministries. Privately owned data centers were of course against the introduction of public regional centers.

After the general election in 1981, a conservative government was formed replacing the Labour government that had appointed the committee. The new Government did not like the idea of regional centers. Since most of the proposals from the committee would cost money, the new Government was not very enthusiastic about those ideas either.

In a report on public data processing presented by the government to the Parliament in 1982, they actually made no concrete proposal. Nevertheless, the Parliament had a long debate about public data processing in 1983 based on the reports from the Government and the committee. Many members of the Parliament were happy for the opportunity to take part in a debate about data processing. The last speaker in the debate, Petter Thomassen from the Conservative Party, remarked:

"I will at the end of the debate like to stress the fact that this has been a special data political day. This has been the first time in the history of the Parliament that we have had such a thorough debate about data processing." 
Thomassen had some of his background from the position as Director of Nordlandsdata, a private computing center in Bod $\varnothing$, and he had been central in the formulation of the Conservative Party data policy (see below and [6]).

Looking back, the greatest sin of omission by the government and the Parliament at that time was the reluctance to go for a vigorous increase in the capacity for education of data professionals. One of the main reasons for cost overruns and scandals in public and private data processing in the eighties and nineties was the lack of qualified data professionals at the decision-making levels. Consequently, the Parliament later got several opportunities for thorough debates about data processing and cost overruns.

The most important results of the committee's work and report was that it led to a stronger interest in and attention to data political questions. Following the presentation of the report in 1978, the political parties competed in establishing their own data policy. Trade unions that did not belong to the Trade Union Congress, also found it necessary to present their own data policy. The increased interest in data processing and data policy resulted in the years 1978-83 in the production of several Government reports and committee deliberations aimed at meeting data political challenges, for instance one on "Computers in school" in 1983 [31] and the start of commission work on "Data technology and societal vulnerability" $[25]^{6}$.

\section{The Political Parties}

\subsection{The Privacy Issue}

The political parties had shown little interest in data political questions in the sixties and the first part of the seventies. A certain interest in the cost of computers and the possibilities for a better public service was of course present. However, there was little concern for the societal consequences of the use of this new technology. One exception was the question of privacy and data protection in the wake of the large computerized files that were a prerequisite for the new social benefit system that was introduced in 1967. But even this question had been brought up and discussed by data specialists long before the politicians showed any interest in it. As an example, a Central Personal Register and a unique personal identity number for all Norwegian citizens had been introduced in 1964 with very little real political debate [2]. However, in 1970 DB-rådet initiated a project at the Department of Civil Law at the Faculty of Law, University of Oslo with a request to study "privacy and governmental data banks". This led to a report [28] and later to the appointment of two government committees to report on problems related to data protection and privacy issues in the private and public sector respectively. The chair of the first committee was Tore Sandvik, a professor of law at the University of Bergen. The committee reported in 1974 [20]. The second committee chairperson was Helge Seip, a newspaper editor and politician (MP 1954-61 and 196573) with experience as a minister in a coalition Government (1965-70) as well as the leader of the liberal party (Venstre). His committee, whose secretary was Arne-Erik Hilmen, reported in 1975 [22]. The committees' work and the lawmakers' conclusions

\footnotetext{
${ }^{6}$ The committee responsible for this report was led by Helge Seip, head of the Data Inspectorate, who had earlier been the leader of the public committee reporting on data protection in the public sector, see next section.
} 
were much inspired by the legislation that had already been introduced in Sweden in 1973. Norway's Data Protection Act was adopted in 1978 and came into use in 1980, after the Data Inspectorate that was a main provision of the law had been established [7]. Helge Seip became the first leader of the Data Inspectorate and Ruth Drolsum of RTV was part of its first board.

\subsection{Each Party Appointed a Data Committee}

Until the end of the seventies, two central data political questions concerned the political parties in Norway. These were computer privacy and the fear of unemployment. The parties on the left were particularly concerned about unemployment and the consequences of new technology in the work place. They also had a concern that private interests would create large databases of consumer profiles for marketing and other commercial purposes. The parties on the right were less concerned about the work place. However, on the question of computer privacy they sided with the left, although their concern would put more weight on the fear of governmental citizen control and Big Brother tendencies. The work leading to the two privacy reports of 1974-75, see above, took the question of privacy out of the political debate in Norway and with it, most other data political questions. For a while, they saw these as less important than the privacy issue.

The debate resulting from the inquiry on de-centralization and improvement of efficiency in public data processing in 1978 led several political parties to appoint committees to formulate proposals for data policies. The Labour Party (Arbeiderpartiet) started its work in 1978. The Christian Democratic Party (Kristelig Folkeparti) followed in 1979 and the Conservative Party (Høyre) in 1980.

Jan Balstad, who was then the leader of NJMF and had been a member of the steering committee of The Iron- and Metal Project, led the Labour Party Data Committee. The Committee members were representatives of the party and important trade unions. Professor Kristen Nygaard and Knut Elgsaas, an early member of the Iron- and Metal Project steering committee, were also members of the Data Committee.

The Data Committee report with recommendations was delivered in 1980 [4]. It had a distinctly positive attitude to the introduction and use of data processing in public service and in private business. Data technology was seen as an important tool for sustaining the competitive power of Norwegian economic life internationally. According to the report, improved data- and telecommunication could make it possible to improve the service level and at the same time free the workers from routine work and give them time for more direct service to clients and customers.

At the time, the fear that the new data- and communication technology would lead to an increase in the level of unemployment was strong. The report therefore stressed that:

"In spite of factors of uncertainty, the Committee will hold on to the conclusion that data technology in the short run may give considerable employment problems, unless the authorities and the trade union bring in countermoves to prevent such a development."

In line with the ideological foundation of the Labour Party, the Committee held that a condition for exploiting the positive effects that may come from the new technology 
was that an active state intervened with measures that would reduce or even remove possible negative consequences of the technology.

The Data Committee proposed several measures that would provide efficient use of new technology, including more education on the use of computers in general, stronger efforts to educate computer specialists, a quality assurance for data systems, and more resources put into computer research.

The Christian Democratic Party Data Committee recommendations [5] were mainly in line with those of the Labour Party proposals. The committee also expressed fears that new technology could lead to unemployment. In the view of the Committee, a higher unemployment level should be met with a more even distribution of paid work. This was in direct discord with the view of the Labour Party Data Committee, which was clearly against using a reduction of working hours as a means to reduce unemployment. The Christian Democratic Party Data Committee also attached more importance to using new technology actively to increase economical and technological development in the Third World. The leader of this committee was Tor Brattvåg who had previously made a report on learning and education for the "Elgsaas committee".

The recommendations of the Conservative Party Data Committee did not differ much from those of the two other Committees. However, on two central points this committee had significantly different views. The Conservative Party Committee [6] did not fear a negative change in employment because of the introduction of new technology. This Committee expected that problems could show up in some branches of the economy, but this could best be met by giving trade and industry better operating conditions. The Committee also meant that competition and the use of tenders should be the normal situation for procurements of computer systems in the public sector. The Labour Party and Christian Democratic Party Committees wanted public acquisitions of computer hardware and software to contribute to the development of a Norwegian data industry.

The leader of the Conservative Party Data Committee was Petter Thomassen, an MP who in 1965, at the age of 24, had been part of the establishment of Nordlandsdata, the first private computer center in the north of Norway, and its first director. Thomassen had been much concerned over computer privacy and had written a book on the topic [32]. He was an outspoken opponent of the proposal of the "Elgsaas committee" to strengthen public data processing in Norway and was of the opinion that free competition was the best solution. In the last half of the eighties Thomassen was Minister of Industry (1985-86) and Minister of Trade and Industry (1989-90).

The data policy proposals from the three committees were already marked by the ideological base views of the respective parties. The result of the ensuing discussions within the parties therefore was mainly an increase in the interest for and attention to data policy questions.

\section{Conclusion}

The rapid development of data technology from 1960 to 1980 was challenging for the public administration, the political parties, and the trade unions. They had to develop a strategy and a policy that could exploit the new possibilities and solve the problems 
that appeared. Their data policy was a means for these three central sectors of society to reach their primary goals and interests. They formed the policies under mutual influence and inspiration. To some extent, the same people in varying roles, often with backgrounds from the same institutions, took part in the work to find an answer to the data political challenges in the three sectors.

That a small number of individuals were the driving forces behind many of the data policy decisions that were formulated during these years should not be seen as the result of some form of conspiracy. In the sixties and seventies, the number of computer experts were few, the number of experts interested in politics and the societal aspects of their special fields of expertise were even fewer. Often these would be colleagues who had been working together in the same institution or been members of the same committees over many years. Of course, they inspired each other and as time went by, they had a common experience that led them to see problems and solutions from the same angle. Add to this that Norway's population was, and still is, small. When forming a committee on the national level or within a political party, there just were not many interested and engaged experts from which to choose.

Finally, it is worth noting that for the most part, the introduction and use of data systems and technology in the public sector and economic life in Norway in the seventies and eighties went without conflicts and problems between employers and employees. This was largely a result of the involvement in data policy by the trade unions and the ensuing introduction of $\$ 12$ in the Working Environment Act.

\section{References}

[1] Arbeids- og sosialdepartementet: Lov om arbeidervern og arbeidsmiljø m.v. (Lov 4.2.1977 nr. 4) (Ministry of Labour and Social Affairs: The Working Environment Act), http: / /www.lovdata.no/oll/nl-19770204-004.html (Last checked September 24, 2007) (ISBN 82-504-1271-0)

[2] Bing, J.: Data Protection in Norway, Norwegian Research Center for Computers and Law (1996),

http: / /www.jus.uio.no/iri/forskning/lib/papers/dp_norway/dp_ norway . html (Last checked July 20, 2007)

[3] Dahl, O.-J., Nygaard, K.: The Development of the Simula Languages. In: Wexelblat, R.L. (ed.) History of Programming Languages. Academic Press, New York (1981)

[4] Datapolitikk. En innstilling og et debattopplegg fra DNA's datapolitiske utvalg (1980) (Data policy. A report and a plan for discussion from the Labour Party Data Committee)

[5] Datateknologien og samfunnet. En innstilling fra datapolitisk utvalg i Kristelig Folkeparti (1980) (DataTechnology and Society. A report from the Christian Democrats Data Committee)

[6] En fremtid med datateknologi. En innstilling fra et utvalg nedsatt av Høyres stortingsgruppe. (A Future with Data Technology. A report from a committee appointed by the Parliament Representatives of the Conservative Party) (1980)

[7] Djønne, E., Grønn, T., Hafli, T.: Personregisterloven med kommentarer (The Data Protection Law, with Comments), Tano, Oslo (1987)

[8] Drolsum, R., Hilmen, A.-E.: Note from Systems Departement, RTV. June 23 (1977)

[9] Elgsaas, K., Hegna, H.: The Norwegian Computing Center and the Univac 1107 (19631970). In: Bubenko Jr., J., Impagliazzo, J., Sølvberg, A. (eds.) History of Nordic Computing: IFIP WG9.7 First Working Conference on the History of Nordic Computing (HiNC1), Trondheim, Norway, June 16-18, 2003. Springer, New York (2005) 
[10] Elgsaas, K.: Myndighetenes forhold til norsk EDB-industri: Foredrag på møte i Den Norske Dataforening 20.10.1977. (The relations between the Government and the Norwegian data industry) A speech at a members meeting in The Norwegian Computer Society October 20 (1977)

[11] Espeli, T. and Elgsaas, K : Datateknologi i et samfunnsmessig perspektiv; (Data Technology from a Social Perspective) in NR 1952-2002, pp. 200-207. Oslo (2002) (see [19] below)

[12] Haraldsen, A.: Den forunderlige reisen gjennom datahistorien (The amazing journey through computer history), Tano-Aschehoug, Oslo, page 87, 130 (1999)

[13] Haraldsen, A.: "The Scandinavian school" i systemutvikling (The Scandinavian School in System Development). In: 50 år og bare begynnelsen, Cappelen, Oslo, ch. 5 (2003)

[14] Innst. S.nr.256 (1974-75). Innstilling fra administrasjonskomiteen om planlegging av databehandling i forvaltningen. (Report on Planning of Goverment Data Processing from the Parliament Administration Committee) (1974-1975)

[15] Kgl. Res. 3.5.1974: Mandat til rådet for databehandling. (Royal Order May 3, 1974: Mandate for "Council for Government Electronic Data Processing")

[16] Norsk Jern- og Metallarbeiderforbund: Referat fra Landsmøtet til NJMF 1970 (Minutes of the Norwegian Iron- and Metal Workers Union National Congress 1970)

[17] Norsk Jern- og Metallarbeiderforbund: Styringskomiteens sluttrapport for forskningsprosjektet B1201, 3143: Planleggingsmetodikk for fagbevegelsen (Final Report from the Steering Committee of Research Project B1201, 3143: Planning Methodology for the Trade Unions), June 29 (1973)

[18] Norsk Regnesentral 1952-2002 (The History of the Norwegian Computing Center 19522002); Norsk Regnesentral, Oslo, September 2002 (in Norwegian)

[19] NOU 1973:43 Planlegging av databehandling i forvaltningen. (The planning of data processing in the government). A report to the Ministry of Consumers Affairs and Government Administration (1973)

[20] NOU 1974:22. Persondata og personvern (Data on Individuals and Protection of Privacy) Report to the Ministry of Justice (1974)

[21] NOU 1974:54:"Elektronisk databehandling i helsevesenet" (Electronic Data Processing in the Health Service). Report to the Ministry of Health (1974)

[22] NOU 1975:10 Offentlige persondatasystem og personvern (Public Databases on Individuals and Protection of Privacy) Report to the Ministry of Justice (1975)

[23] NOU 1976:30 Perspektivanalyse for norsk elektronikkindustri (A perspective analysis for Norwegian electronic industry), A report to the Ministry of Industry (1976)

[24] NOU 1978:48: Offentlig databehandling. Desentralisering og effektivisering. (Public Data Processing. Decentralization and increased efficiency). Report to the Ministry of Consumers Affairs and Government Administration 1978.

[25] NOU 1986:12 Data-teknologi og samfunnets sårbarhet (Data Technology and Societal Vulnerability) (1986)

[26] Nygaard, K., Bergo, O.: Planlegging, styring og databehandling. Grunnbok for fagbevegelsen (Planning, Control, and Data Processing, A basic textbook for the Trade Unions) Tiden forlag, Oslo (1974)

[27] Rådet for elektronisk databehandling i Staten (Council for Government Electronic Data Processing): Organisering av databehandlingsvirksomheten i forvaltningen (Organization of data processing within the government) (June 1980)

[28] Samuelsen, E.: Statlige databanker og personlighetsvern (Public Databases and Protection of Privacy) Norwegian University Press, Oslo (1972) 
[29] St. melding nr. 37 (1974-1975): Om planlegging av databehandlingen i forvaltningen (Planning of data processing in Government) Statement to the Parliament from the Ministry of Consumers Affairs and Government Administration (1974)

[30] St. melding nr.12 (1982-1983): Desentralisering og effektivisering i den offentlige databehandlingen (Decentralization and increased efficiency in public data processing). Statement to the Norwegian Parliament from the Ministry of Consumers Affairs and Government Administration (1982)

[31] St. meld. nr. 39 (1983-84) Datateknologi i skolen (Computers in School). Statement to the Norwegian Parliament from the Ministry of Education and Church Affairs (1983)

[32] Thomassen, P.: Privatliv og EDB: hvordan kan vi beskytte oss? (The private sphere and computer processing: How can we protect ourselves?) Cappelen, Oslo (1977) 